\title{
Use of Biotechnology to Create or Transfer Novel Traits in Tomato
}

\author{
Martha A. Mutschler \\ Department of Plant Breeding and Biometry, Cornell University, Ithaca, NY 14853
}

The tomato (Lycopersicon esculentum) is often cited as an example of success in plant breeding and of potential for further improvement through use of biotechnology. The interest in tomato as a model system for genetic engineering is due in part to the large body of work done on the genus Lycopersicon over the past 50 years. This work includes the collection of germplasm of L. esculentum and its wild relatives, creation of chromosome addition and translocation stocks, the discovery or creation of $>1200$ monogenic mutants (Stevens and Rick. 1986). transfer from wild species of dis ease resistance genes. the creation of near-isogenic lines for a num ber of mutants or resistance genes, and the development of the clas sical genetic map (Tanksley et al., 1990). which has >300 markers including mutants, isozymes and resistance genes. The attractiveness of tomato as a research system also is due to the characteristics of the species that lend it to genetic work. L. esculentum and its wild relatives are diploid species, $2 \mathrm{~N}=24$, and are amenable to cyto logical study. L. esculentum is easy to self-pollinate or cross, resulting in relatively high seed set. L. esculentum has a relatively small genome $(0.7 \mathrm{pg})$. which has remarkably few duplicate loci (Rick, 1971; Tanksley et al., 1987). An excellent central resource on the cultivation, genetics, and biology of L. esculentum and its wild relatives is the book "The Tomato Crop" (Astherton and Rudich, 1986). Lists of the plant materials available in Lycopersicon can be found in the yearly publication Reports of the Tomato Genetic Cooperative. In a recent article. Hille et al. (1989) summarized the use of biotechnology, in the broadest sense of the term, in tomato improvement. Rather than repeat material in that excellent article. the focus of this discussion is to overview the pos sibilities and the potential value of the use of emerging technologies for tomato improvement.

Progress to date in using molecular developments for plant im provement centers on two molecular techniques. The creation/use of RFLP maps and the introduction of foreign DNA into the plant genome using Ti-mediated gene transfer. If one also considers tis sue culture under the rubric of "biotechnology", the possibility of plant improvement by protoplast fusion and regeneration also may be considered.

The current tomato RFLP map is probably one of the most com plete maps of a higher plant genome (Tanksley et al., 1990). Once created. the RFLP map has several uses for plant improvement. The map can be used to locate and identify molecular makers for genes of interest (Young and Tanksely. 1989). Once closely linked molecular markers have been identified. the markers can be used in indirect screening for the gene of interest. and so facilitate the rapid transfer of desired major genes while minimizing linkage drag (Tanksley et al.. 1989; Tanksley, 1989). RFLP mapping can be used further to identify the regions of the genome that are associat ed with important quantitative traits. Once these regions are identi fied, the information can be used to facilitate the transfer of genes affecting the quantitative trait (Paterson et al., 1988; Tanksley et al.. 1989).

The value of the RFLP map for single genes or quantitative traits is evident. These techniques are currently being used in a number of laboratories focusing on diverse traits. The disadvantages of the systems are the cost and time involved, which can be minimized by careful planning, and the need in tomato to use plants derived from interspecific crosses to acquire sufficient polymorphisms. However. the advantages of the systems definitely exceed the disadvantages.
Regeneration of tomato plants from protoplasts, either directly or following protoplast fusion, is possible in tomato with a moderate degree of difficulty (O'Connell and Hanson. 1986, 1987). Alterations of cytoplasmic genomes using protoplast fusion are, therefore, also possible, and are of interest to generate plants with traits such as cytoplasmic male sterility or herbicide resistance. Regeneration of tomato plants from explants can be done routinely in tomato, although the cultivar used has an impact on the frequency of regeneration. The ability to regenerate plants from explants is one of the characteristics needed for transformation using Ti-medi ated gene transfer.

Transformation of tomato using a modified $\mathrm{Ti}$ plasmid is routine, if not as easy as that in tobacco or petunia. Transformation using Ti plasmids has been used to introduce genes from other plant or bacterial species into tomato. The toxin produced by Bacillus thuringiensis (BT) is a protein that is toxic to the larvae of many lepidopteran (moth and butterfly) pests (Aronson et al., 1986). The toxin has been used as a spray for a number of years, and has no toxicity to other animals, including beneficial insects or mammals (Klausner, 1984). Although the question remains as to whether constitutive expression of BT by transgenic plants would result in development of insects resistant to the toxin; Ti-mediated transfer of one or more forms of the BT gene is being pursued widely as a means to rapidly confer insect resistance to crop species, including tomato (Delannay et al., 1989; Fischhoff et al., 1987). Ti-mediated transfer of a gene for BT toxin confers the ability to produce the toxin in sufficient quantity to confer resistance to lepidopterous pests under laboratory (Fischhoff et al.. 1987) and field (Delannay et al., 1989) conditions.

Resistance to herbicides has been created by two approaches. The first approach is the insertion of a resistant allele of the enzyme that is the target of the herbicide. An example of this approach is the creation of glyphosate-resistant plants by the insertion of a resis tant allele of bacterial origin of the enzyme 5-enolpyruvylshikimate-3-phosphate syntherase. which is the specific target of glyphosate (Fraley et al. 1988). The second approach is the insertion of a gene that detoxifies the herbicide. An example of this approach is the insertion of the bar gene of Streptomyces hygroscopicus, which detoxifies the herbicides bialaphos and phosphinothricin (DeBlock et al., 1989).

Genes for virus coat proteins have been introduced into tomato. potato, and tobacco in attempts to create virus resistance (Baulcombe, 1989). Success has been reported in tomato for a number of viruses, including tobacco mosaic virus and cucumber mosaic virus (Turner et al.. 1981; Nelson et al., 1988). While there is some indication that the systems may be limited by virus strain or titer of infection, this is a promising system for creation of resistance to be used in conjunction with natural resistances, or until additional sources of resistance are found. A related approach to the insertion of a coat protein gene to create virus resistance is the insertion of a modified gene producing antisense mRNA for the coat protein. This approach has not given as high a level of resistance as the use of the normal coat protein gene. and so is not as promising (Cuozzo et al., 1988; Rezalan et al., 1988).

The study and cloning of transposons, chiefly $A C$ and $D s$ of maize. has let to transposon tagging and cloning of genes of interest (Fedoroff et al.. 1984). This is an exciting development. Since many genes of interest are genes for which protein products and mRNAs have not been identified. these genes can not be isolated 
readily from genomic and cDNA libraries. Transposon tagging al lows the localization and cloning of a gene without the knowledge of the gene product or the availability of a heterologous clone. once a gene of interest is tagged and cloned. the gene could be studied, modified, and/or transferred to other crop species. Transposons have been introduced into several dicot species, including tobacco (Baker et al., 1986, 1987) and tomato (Yoder et al., 1988) using Ti-mediated transformation. Since the transposons are capable of excision and transposition in these species, the insertion of the transposons will permit transposon tagging and cloning of genes of interest.

The most recent use of transformation is the insertion of antisense constructs of genes into a plant to down-regulate the expression of a gene. This approach works by the production of antisense RNA. which hybridizes to the normal transcripts for the gene, effectively reducing the level of mRNA of the normal gene available for translation. This protocol has been used successfully to down-regu late the ripening-related enzyme polygalacturonase in tomato fruit (Smith et al., 1988; Sheehy et al.. 1988: Schuch et al.. 1989).

It is evident that each of these technologies can be useful for basic studies. The advantages and limitations of these technologies. and the extent to which each might contribute to the improvement of tomato and related crops, will be seen over the 10 years. RFLP maps are currently of use in dealing with both single genes and with quantitative traits. The ability to transform tomato plants is already being used for many research purposes. The major limitation of transformation in plant improvement may be due to the current restrictions in handling transformed plants. Until society decides on how to permit use of transformed plants in agriculture, the use of transformed plants is limited to basic research.

\section{Literature Cited}

Aronson, A.I.. W. Beckman, and P. Dunn. 1986. Bacillus thuringensis and related insect pathogens. .Microbiol. Rev. 50:1-24.

Atherton. J.G. and J. Rudich. 1986. The tomato crop. Chapman and Hall, London.

Baker, B., G. Coupland, N. Fedoroff, P. Starlinger, and J. Schell. 1987. Phenotypic assay for excision of the maize controlling elements AC in tobacco. EMBO J. 6: 1547-1554.

Baker, G.. J. Schell. H. Lore. and N. Fedoroff. 1986. Transposition of the maize controlling element "Activator" in tobacco. Proc. Natl. Acad. Sci USA 83:4844-4848.

Baulcombe. D. 1989. Strategies for virus resistance in plants. Trends Genet. 5:56-60.

Cuozzo. M., K.M. O'Connell, W. Kaniewski, R.X. Fiang. N.H. Chua, and N.E. Turner. 1988. Viral protection in transgenic tobacco plants expressing the cucumber mosaic virus coat protein or its antisense RNA. Bio/Technology 6:549-557.

DeBlock. M., J. Botterman, M. Vandewiele, J.. Dockx, C. Thoen, V. Gossele, N. Rao Movva. C. Thompson, M. Van Montagu. and J. Leemans. 1987. Engineering herbicide resistance in plants by expression of a detoxifying enzyme. EMBO J. 6:2513-2518.

Delannay, S.. B.J. LaVallee, R.K. Proksch, R.L. Fuchs, S.R. Sims, J.T. Greenplate. P.G. Marrone. R.B. Dodson. J.J. Augustine. J.G. Layton and D.A. Fischhoff. 1989. Field performance of transgenic tomato plants expressing the Bacillus thuringlensis var. Kurstaki insect control protein Bio/Technology 7:1265-1269.

Fedoroff. N.. D. Furtek, and O. Nelson. 1984. Cloning of the bronze locus in maize by a simple and generalizable procedure using the transposable controlling element activator (Ac). Proc. Natl. Acad. Sci. USA 81:3825-3829.

Fischhoff, D.A., K.S. Bowdish. F.J. Perlak. P.G. Marrone. SM. McCormick. J.B. Niedermeyer, D.A. Dean, K. Kusnao-Kretzmer. E-J.. Mayer, D.E. Rochester. S.G. Rogers, and R.T. Fraley. 1987. Insect tolerant transgenic tomato plants. Bio/Technology 5:807-813.

Fraley. R.T., S.G. Rogers. R.B. Honch. G.M Kishore, R.N. Beachy. N.N. Turner. D.A. Fischhoff. X. Delannay. H.J. Klee. and D.M. Shah. 1988. Generic engineering for crop improvement, p. 283-289. In: J.P. Gustafson and R. Appels (eds.). Chromosome structure and functionimpact of new concepts. Plenum, New York.

Gasser, C.S.. and R.T. Fraley. 1989. Genetically engineering plants for crop improvement. Science 244: 1293-299.

Hille, J., U. Koomeff, M.S. Ramanna, and P. Zabel. 1989. Tomato: a crop species amenable to improvement by cellular and molecular methods. Euphytica 42:1-23

Klausner, A. 1984. Microbial insect control using bug to kill bugs. Bio/ Technology: 408-419.

Nelson, R.S., S.M. McCormick. X. Delannay. P. Dube. J. Layton, E.J. Anderson, M. Kanienska, R.K. Proksch. R.B. Horsch. S.G. Rogers, R.T. Fraley. and R.N. Beachy. 1988. Virus tolerance. plant growth. and field performance of transgenic tomato plants expressing coat protein from tobacco mosaic virus. Bio/Technolcgy 6:603409.

O'Connell, M.A., L.P. Hosticka. and M.R. Hanson. 1986. Examination of genome stability in cultured Lycopersicon. Plant Cell Rpts. 5:276-279.

O'Connell, M.A. and M.R. Hanson. 1986. Regeneration of somatic hybrid plants formed between Lycopersicon esculentum and Solanum rickii. Theor. Applied Genet. 72:59-65.

O'Connell. M.A. and M.R. Hanson. 1987. Regeneration of somatic hybrid plants formed between Lycopersicon esculentum and L. pennelli. Theor. Applied Genet. 75:83-89.

Paterson. A.H.. E.S. Lander, I.D. Hewitt. S. Peterson. S.E. Lincoln, and S.D. Tanksley. 1988. Resolution of quantitative traits into Mendelian factors by using a complete linkage map of restriction fragment length polymorphisms. Nature: (London) 335:721-726.

Rezaian. MA., K.G..M. Skene. and J.G. Ellis. 1988. Anti-sense RNAs of cucumber mosaic virus in transgenic plants assessed for control of the virus. Plant Mol. Biol. 11:463-471.

Rick. C.M. 1971. Some cytoplasmic features of the genome in diploid plant species. Stadler Symp. 1\&2:153-174.

Schuch. W., C. Bird, J. Ray, C. Smith, C. Watson, P. Morris, J. Gray, C. Arnold. G. Seymour, G. Tucker. and D. Grierson. 1989. Control and generic manipulation of gene expression during tomato fruit ripening. Plant Mol. Biol. 13:303-312.

Sheehy, R.E.. M. Krammer. and W.R. Hiatt. 1988. Reduction of polygalacturonase activity in tomato fruit by antisense RNA. Proc. Natl. Acad. Sci. USA 85:8805-8809.

Smith. C.J.S., C.F. Watson. J. Ray. C.R. Bird, P.C. Morris. W. Schuch. and D. Grierson. 1988. Antisense RNA inhibition of polygalacturonase gene expression in transgenic tomatoes. Nature (London) 334:724-726.

Stevens, M.A. and C.U. Rick. 1986. Genetics and breeding. p. 35-109. In: J.G. Atherton and J. Rudich (eds.). The tomato crop. Chapman and Hall. London.

Tanksley, S.D.. N.D. Young, A.H. Paterson. and M.W. Bonierbale. 1989. RFLP mapping in plant breeding: new tools for an old science. Bio/ Technology 7:257-264.

Turner. N.E.. K. O'Connell, R. Nelson, P. Sanders, R. Beachy. R Fraley, and D. Shah. 1987. Expression of alfalfa mosaic virus coat protein gene confers cross-protection in transgenic tobacco and tomato plants. EMBO J. 6:1181-1188.

von Wettstein. D. 1989. Perspectives for the genetic engineering of plants for agriculture. horticulture. and industry. Plant Mol. Biol. 13:313-318.

Yoder, J.I.. J. Palys. K. Alpert,. and M. Lassner. 1988. Ac transposition in transgenic tomato plants. Mol. Gen. Genet 213:291-296. 